\title{
The Effect of Intraoperative Injection of Hyaluronan under a One-Piece Glaucoma Filtration Implant in the Rabbit Eye
}

\author{
By M. Kivalo, T. Hollmén, A. Sukura and T. Mononen
}

Section of Anatomy, Department of Basic Veterinary Sciences, Faculty of Veterinary Medicine, University of Helsinki, Finland.

\begin{abstract}
Kivalo, M., T. Hollmén, A. Sukura and T. Mononen: The effect of intraoperative injection of hyaluronan under a one-piece glaucoma filtration implant in the rabbit eye. Acta vet. scand. 1997, 38, 235-242. - The effect of a single intraoperative injection of hyaluronan on intraocular pressure (IOP) and postsurgical tissue healing was evaluated on 18 rabbits with an aqueous drainage implant. During the follow-up period IOP was recorded and analysed. Furthermore, inflammatory reaction and appearance of the fibrous tissue around the implants were studied in histological sections.

In both the hyaluronan and control groups the operation lowered the average IOP statistically significantly for the whole follow-up period when compared with preoperative values. From days 7 to 60 the mean IOP values of the hyaluronan injected eyes stayed at a lower level than in the control eyes, but with no statistical difference between the 2 groups.

The connective tissue layer around the implants appeared less dense during the first 17 postoperative days in the sodium-hyaluronate group; in addition, the inflammatory cell reaction showed a tendency to remain acute longer.
\end{abstract}

intraocular; pressure; glaucoma; surgery, histology.

\section{Introduction}

Even biocompatible materials, such as silicone, used in surgical operations can evoke an inflammatory reaction and subsequent fibrosis in the tissues. A common cause for failure in glaucoma implant surgery is the formation of excessive scar tissue around the drainage system (Skuta \& Parrish 1987). Such tissue will prevent the formation of a functional filtering bleb and hinder the flow of aqueous humor from the anterior chamber to the conjunctival tissue, causing a rise in intraocular pressure (IOP). Control of wound healing process is therefore important in achieving surgical success.

Pharmacological modification of wound heal- ing in association with glaucoma filtration surgery has been intensively studied: Molteno (1976) used anti-inflammatory drugs to control bleb fibrosis. The antifibrotic agents 5-fluorouracil and mitomycin- $\mathrm{C}$ were introduced as an adjunct to glaucoma surgery in the 1980 s and early 1990s (Lee et al. 1987, Chen et al. 1990). Both in experimental work with animals (Khaw et al. 1993, Pasquale et al. 1992) and in clinical studies with human patients (Watanabe et al. 1991, Skuta et al. 1992) these agents have a beneficial effect on surgery outcome. Nevertheless, several complications, including corneal epithelial defects, wound leakage, and chor- 
oidal and retinal detachment, have been reported in relation to the use of 5-fluorouracil and mitomycin-C (Shapiro et al. 1985, Kitazawa et al. 1991, Franks \& Hitchings 1991).

Unlike these agents, hyaluronan is present in most tissues in man and animals. It has an influence on cell motility, and on synthesis, differentiation and regulation of extracellular matrix components (Laurent \& Fraser 1992). Wound healing in diabetic rats (Abatangelo et al. 1983) was enhanced by topical application of hyaluronan. Full thickness, linear skin incisions in monkeys, rabbits and guinea pigs, showed less scar formation when treated with hyaluronan (Rydell 1970). Longaker et al. (1991) suggested that fetal wound healing, characterised by lack of fibrosis and scar formation, is partly a consequence of high concentration of hyaluronan in the fetal extracellular matrix.

The aim of the present study is to evaluate the effect of a single intraoperative injection of high molecular-weight sodium hyaluronate under the subconjunctival part of an ocular drainage implant on intraocular pressure and postsurgical inflammatory response in the rabbit eye.

\section{Materials and methods}

Implants used in this study were built as described previously (Kivalo et al. 1992). A small notch was cut in one side wall of a $10 \mathrm{~mm}$-long silicone strip with a U-shaped cross section (Retinal Detachment Band no 20, Storz, ST. Louis, MO, U.S.A.); then a $10 \mathrm{~mm}$-long medical-grade silicone tube was adhered to the notch with silicone medical adhesive $\left(\right.$ Silastic $^{\mathrm{R}}$, Dow Corning, Midland, MI, U.S.A.). The outside diameter of the tube was $0.64 \mathrm{~mm}$ and the inside diameter $0.3 \mathrm{~mm}$. Both ends of the tube were bevelled to a $45^{\circ}$ angle to maximize the opening. Sharp edges at both ends of the silicone strip were rounded off.

Surgery was performed on 18 adult albino rab- bits with normal IOP. The rabbits were anaesthetized with a combination of xylazin hydrochloride $5 \mathrm{mg} / \mathrm{kg}$ (Rompun ${ }^{\mathrm{R}}$, Bayer AG, Leverkusen, Germany) and ketamine hydrochloride $15 \mathrm{mg} / \mathrm{kg}$ (Ketalar ${ }^{\mathrm{R}}$, Parke-Davis, S.A. Barcelona, Spain) intramuscularly. The cornea and conjunctiva were topically anaesthetized with oxybuprocaine hydrochloride (Obucain ${ }^{\mathrm{R}}$, $4 \mathrm{mg} / \mathrm{ml}$, Star, Tampere, Finland). Topical anaesthesia was used as a precaution to avoid the addition of anaesthetics in the final stages of the operation (i.e. dexamethasone injection) and unnecessarily lengthening the anaesthesia.

Under an operating microscope a dorsal limbal incision was made, through which a fornixbased pocket was formed by separating conjunctiva and Tenon's capsule from the sclera. The implant was inserted into the pocket, the concave side facing the sclera. It was sutured at both ends with 8-0 silk suture (Virgin Silk ${ }^{\mathrm{R}}$, Ethicon LTD. U.K.) to the sclera. A $23 \mathrm{G}$ needle was used to penetrate the cornea into the anterior chamber at the limbus. The silicone tube was cut to a length to reach the pupil and was inserted into the anterior chamber through the needle tract, avoiding contact with the corneal endothelium. In the right eye of each animal, $0.1 \mathrm{ml}$ of sodium hyaluronate (Hylartil $^{\mathrm{R}}$ vet, Pharmacia AB, Uppsala, Sweden) was injected under the subconjunctival part of the implants. Then the conjunctiva was tightened over the implants and sutured with a continuous 8-0 silk suture (Virgin Silk ${ }^{\mathrm{R}}$, Ethicon LTD) at the limbus. The left eye, which served as a control, was operated in an identical manner, but instead of sodium hyaluronate, $0.1 \mathrm{ml}$ of physiological saline was injected under each implant. All animals received an injection of $0.4 \mathrm{mg}$ dexamethasone phosphate (Fortecortin ${ }^{\mathrm{R}}$, Merck, Germany) into the ventral subconjunctival tissues. For all animals, trimethoprim $2.5 \mathrm{mg} / \mathrm{kg}$ and sulphadoxine $12.5 \mathrm{mg} / \mathrm{kg}$ (Borgal $^{\mathrm{R}}$ vet, Hoechst AG, München, Germany) were used subcutane- 
ously as systemic antibiotic for 4 days. Chloramphenicol eye ointment (Oculo-Klorita ${ }^{\mathrm{R}}, 10$ $\mathrm{mg} / \mathrm{ml}$, Lääkefarmos, Turku, Finland) and atropin (Oftan Atropin ${ }^{\mathrm{R}}, 1 \%$, Star, Tampere, Finland) was locally applied twice a day for 4 days. Biomicroscopical examination and measurement of the IOP with a hand-held applanation tonometer (Tonopen $^{\mathrm{R}}$, Oculab, Glendale, CA, U.S.A.) was carried out daily for the first 3 postoperative days and then once a week for the rest of the follow-up period of 2 months. To avoid any fluctuation in the IOP the measurements were always carried out at the same time of the day.

The animals were divided into 4 groups for the follow-up periods of 7, 17, 30 and 60 days. Three of the groups comprised 4 animals each, but the 60-day group 6 animals.

After the follow-up periods the animals were anaesthetized with the combination of Rompun $^{R}$ and $\operatorname{Ketalar}^{\mathrm{R}}$ described above and then euthanized with an intracardial injection of euthanasia solution $\left(\mathrm{T} 61^{\mathrm{R}}\right.$, Hoechst Veterinär $\mathrm{GmbH}$, München, BRD). The eyes were enucleated and immediately fixed in $10 \%$ neutral phosphate-buffered formalin. For histological examination the eyes were embedded in paraffin and cut with a microtome to $4 \mu \mathrm{m}$-thick sections and stained with Haematoxylin-Eosine, Toluidine Blue and Herovic connective tissue stains. The sections were read blindly and changes in fibrous tissue and inflammatory cell reaction were graded.

The mean IOP's of each right and left eye were calculated and analysed with a paired t-test for the whole postoperative period. Statistical analyses were carried out with the Statistix ${ }^{\mathrm{R}}$ (Analytical Software, St. Paul, MN, USA) analytical software package.

The use of research animals in this study was approved by the ethical committee of The Faculty of Veterinary Medicine, University of Helsinki.

\section{Results}

At the site of surgery, local oedema and hyperemia was seen during the first week after the operation. Fibrin accumulations were noted in the anterior chamber on the first postoperative day, mostly around the silicone tubes and between the tubes and the anterior side of the iris. Most of the fibrin disappeared from the anterior chambers between the third and seventh postoperative days, the remaining fibrin being adherent to the outer surface of the tubes.

No marked changes in anterior chamber depths were seen during the follow-up period. After the operation the anterior chambers were shallow for 1 to 3 days. At inspection after the seventh day, no shallow anterior chambers were noted. No differences were noted between the hyaluronan-injected and control eyes.

Three implants in the control group on days 7 , 14 , and 21 , eroded through the conjunctiva and had to be removed. In the hyaluronan-injected eyes one implant eroded through the conjunctiva on day 21 .

\section{Intraocular pressure}

The operation lowered the average IOP statistically significantly in both eyes for the whole follow-up period compared with preoperative values $(\mathrm{p}<0.001)$.

After surgery the average postoperative IOP for the whole follow-up period was $9.7\left(\mathrm{CI}^{95 \%}: 8.5\right.$ 10.9) $\mathrm{mmHg}$ in the hyaluronan-injected eyes and 10.3 ( $\mathrm{CI}^{95 \%}$ : 9.2-11.4) $\mathrm{mmHg}$ respectively in the control eyes.

No statistically significant difference $(\mathrm{p}=0,20)$ was found between the hyaluronan-injected and control eyes during the follow-up period.

The IOPs for the 2 groups did not differ during the first postoperative week, but thereafter there seemed to be a tendency for the IOP of the hyaluronan-injected eyes to be lower than that of the control eyes. In Fig. 1 the postoperative IOP's of control and hyaluronan-injected eyes 


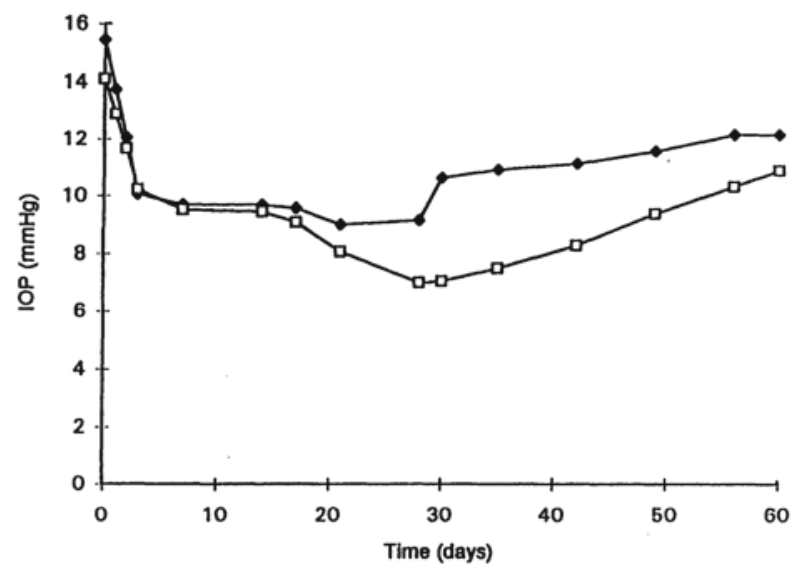

Figure 1. Postoperative IOP's of control eyes $(\bullet)$ and hyaluronan-injected eyes $(\square)$ during follow-up, presented as a moving average of 3 consecutive measurements.

during the follow-up period are presented as a moving average of 3 consecutive measurements.

\section{Histology}

Changes in fibrous tissue and relative abundance of inflammatory cells are presented in Table 1 .
On day 7 , the implant cavities were surrounded by thick, loose connective tissue layer in which fibroblasts were abundant (Figs. 2a and 2b). The reaction was most prominent at the anterior and posterior edges and ventral to the implants. In hyaluronan-injected eyes, the reaction appeared more oedematous and vascular (Fig. 2b). On days 17 and 30 , the reaction had ma-

Table 1. Histological changes during the follow-up period in control eyes and hyaluronan-injected eyes.

\begin{tabular}{|c|c|c|c|c|c|c|c|c|}
\hline & \multicolumn{4}{|c|}{$\begin{array}{l}\text { Control eyes } \\
\text { Days }\end{array}$} & \multicolumn{4}{|c|}{$\begin{array}{c}\text { Hyaluronan-injected eyes } \\
\text { Days }\end{array}$} \\
\hline & $\begin{array}{c}7 \\
n=4\end{array}$ & $\begin{array}{c}17 \\
n=4\end{array}$ & $\begin{array}{c}30 \\
\mathrm{n}=3\end{array}$ & $\begin{array}{c}60 \\
n=5\end{array}$ & $\begin{array}{c}7 \\
n=4\end{array}$ & $\begin{array}{c}17 \\
\mathrm{n}=4\end{array}$ & $\begin{array}{c}30 \\
\mathrm{n}=2\end{array}$ & $\begin{array}{c}60 \\
n=6\end{array}$ \\
\hline \multicolumn{9}{|l|}{ Fibrous tissue: } \\
\hline Density & + & + & ++ & ++ & +- & + & ++ & +++ \\
\hline Amount of fibroblasts & +++ & + & + & +- & +++ & + & + & +- \\
\hline Vascularisation & ++ & + & +- & - & ++ & + & +- & - \\
\hline \multicolumn{9}{|l|}{$\begin{array}{l}\text { Inflammatory cell } \\
\text { reaction: }\end{array}$} \\
\hline Polymorphonuclear & & & & & & & & \\
\hline $\begin{array}{l}\text { leucocytes } \\
\text { Mononuclear }\end{array}$ & ++ & + & +- & +- & +++ & ++ & +- & +- \\
\hline leucocytes & ++ & ++ & ++ & + & + & ++ & + & + \\
\hline
\end{tabular}

Findings are graded from - (not found) to +++ (marked). $n=$ the number of examined eyes in each group. 

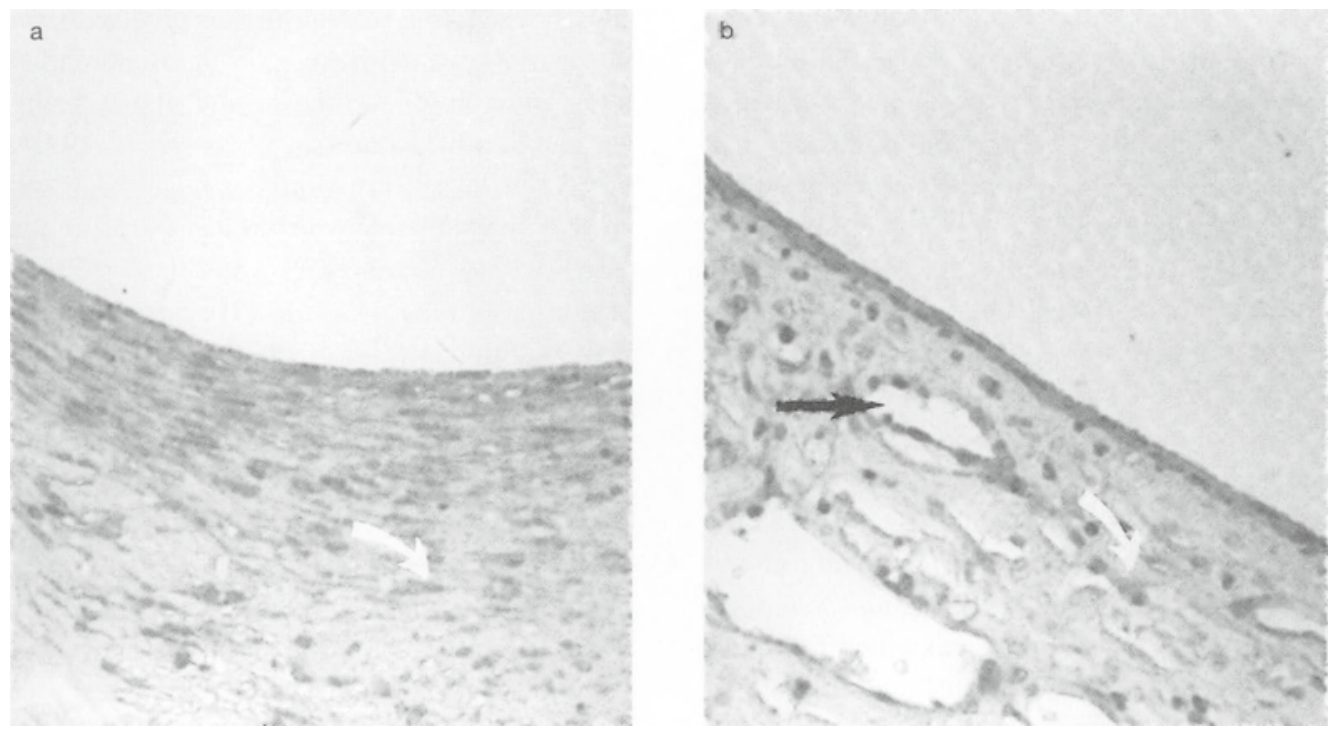

Figures $2 \mathrm{a}$ (control eye) and $2 \mathrm{~b}$ (hyaluronan-injected eye). On day 7 , fibroblasts (white arrows) are abundant in the thick connective tissue reaction surrounding the implant. In the hyaluronan-injected eye, the tissue reaction appeared more oedematous and dilated capillaries (black arrows) were abundant in the reaction (2b). Hematoxylin-Eosin. Orig magnified $200 \times$.
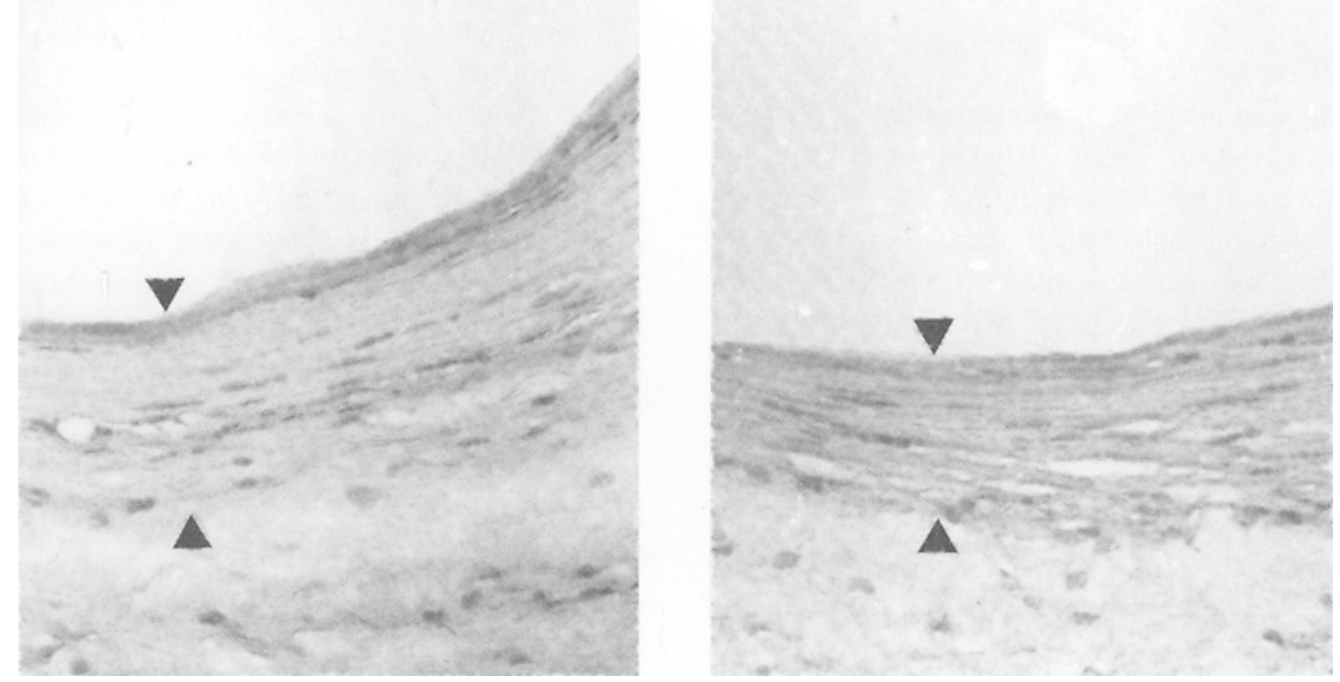

Figures $3 \mathrm{a}$ (control eye) and $3 \mathrm{~b}$ (hyaluronan-injected eye). On day 60, connective tissue (between arrowheads) is seen as a well-organized, thin rim surrounding the implant, with no histological differences noted between control and hyaluronan-injected eyes. Hematoxylin-Eosin. Orig magnified $200 \times$. 
tured gradually and on day 60 , only a thin rim of collagen fibers arranged in parallel bundles were seen surrounding the implant cavities (Figs. 3a and 3b). At this point, no histological differences were noted in the fibrous tissue reaction between the 2 groups.

A mixed inflammatory cell reaction was present in both groups. On day 7, polymorphonuclear leucocytes were the predominant cell type in the hyaluronan-injected eyes, whereas in control eyes polymorphonuclear and mononuclear leucocytes were seen in equal numbers. Towards day 60 the inflammatory cell reaction became gradually milder and polymorphonuclear leucocytes fewer in both groups, but polymorphonuclear leucocytes remained more numerous in hyaluronan-injected eyes throughout the experiment.

It is noteworthy, that in both eyes a marked, polymorphonuclear inflammatory reaction was seen surrounding the suture materials. The local inflammatory reaction was more severe and remained acute longer around the suture material than around the implants.

\section{Discussion}

Hyaluronic acid, now also called hyaluronan (Laurent \& Fraser 1986), is a non-sulphated glycosaminoglycan comprised of repeating disaccharide units of D-glucuronic acid linked to $\mathrm{N}$-acetyl-D-glucosamine (Jackson et al. 1991). It is a structural element of connective tissue extracellular matrix which occurs in high concentrations in synovial fluid, vitreous and umbilical cord (Comper \& Laurent 1978).

Hyaluronan has an effect on many events in wound healing. It regulates granulocyte function (Håkansson \& Venge 1987) and the rate of proliferation of fibroblasts (Goldberg \& Toole 1987).

Weigel et al. (1986) presented a model for the early events in wound healing where the hyaluronan-fibrin matrix plays a major role in the subsequent tissue reconstruction process. Like the scarless wound healing in the mammalian fetus, possibly due to the wound matrix being enriched with hyaluronan (Mast et al. 1992), decreased scar formation has also been reported in tympanic membrane perforations (Hellström \& Laurent 1987) and flexor tendon lacerations (Amiel et al. 1989) after treatment with hyaluronan.

In ophthalmic surgery, hyaluronan, in the form of sodium-hyaluronate, has been used for the last 2 decades, for instance as a vitreous replacement (Balazs et al. 1972) and to protect corneal endothelium during intraocular lens implantation (Alpar 1984). In glaucoma surgery Na-hyaluronate has been used to prevent the formation of a flat anterior chamber after fistulation (Raitta \& Setälä 1986) or to elevate the conjunctiva at the site of the filtration bleb (Pape \& Balasz 1980).

The effect of hyaluronan on scar formation in ophthalmic surgery has been studied by Arzeno \& Miller (1982), Kivalo \& Raitta (1991) and Wirt et al. (1992). In the study by Kivalo \& Raitta hyaluronan's effect on scar formation was evaluated by measuring the thickness of fibrous tissue under a subconjunctival silicone implant which, unlike the implant used in this study, was not connected with the anterior chamber. Although no statistically significant difference could be shown the thickness of scar tissue under the implants treated with hyaluronan was greater than in the control eyes during the first seventeen postoperative days. Also the inflammatory response in hyaluronan-injected eyes in the early postoperative period was more noticeable than in control eyes, a finding similar to this experiment.

In the present study differences were noted in the quality of the connective tissue reaction between the hyaluronan-injected and control eyes. On day 7, the connective tissue in the hyaluronan-injected eyes appeared less dense, 
more oedematic and more vascular. In this group, the fibroblasts also appeared more immature than in the control eyes, differences still noticeable on day 17 .

Histological differences were also noted in polymorphonuclear - mononuclear leucocyte ratio. After the first postoperative week, polymorphonuclear cells were more numerous than mononuclear cells in the hyaluronan-injected eyes, and they remained longer in the inflammatory cell reaction in this group throughout the follow-up period.

In both the hyaluronan-injected and control eyes the average postoperative IOPs were statistically significantly lower than preoperative values. Although lower mean IOP values were seen from days 7 to 60 in the hyaluronantreated eyes compared to controls, its clinical importance is probably neglectable. Towards the end of the follow-up period the difference in mean IOP values between the 2 groups showed a tendency to decrease.

The lower pressure-values for the hyaluronaninjected eyes can probably be better explained by the quality than by the thickess of the fibrous capsule surrounding the implants. Because the connective tissue reaction appeared less dense and more vascular in the hyaluronan-injected eyes, these differences may imply, for this group, greater tissue permeability and easier movement for the aqueous through the bleb wall.

In conclusion, in the eyes treated with a single hyaluronan injection a small reduction in IOP values from the second postoperative week to the end of the follow-up period was seen. A larger dose or repeated injections might alter the results in regard of the amount and duration of the IOP reduction.

\section{Acknowledgements}

This work was supported by a grant from The Finnish Foundation of Veterinary Medicine (MK) and
The Research and Science Foundation of Farmos (AS).

\section{References}

Abatangelo G, Martelli M, Vecchia P: Healing of hyaluronic acid-enriched wounds: Histological observations. J. Surg. Res., 1983, 35, 410-416.

Alpar JJ: Endothelium protection using Healon ${ }^{\mathrm{R}}$, serum or air in cataract extraction and intraocular lens implantation. J. Ocul. Ther. Surg., 1984, 3, 229-233.

Amiel D, Ishizue K, Billings E, Wiig M, Vande Berg J, Akeson WH, Gelberman R: Hyaluronan in flexor tendon repair. J. Hand. Surg., 1989, 14, 837-843.

Arzeno $G$, Miller D: Effect of sodium hyaluronate on corneal wound healing. Arch. Ophthalmol., $1982,100,152$.

Balazs EA, Freeman MI, Klöti R, Meyer-Schwickerath $G$, Regnault $F$, Sweeney $D B$ : Hyaluronic acid and replacement of vitreous and aqueous humor. Mod. Probl. Ophthalmol., 1972, 10, 3-21.

Chen CW, Huang HT, Bair JS, Lee CC: Trabeculectomy with simultaneous topical application of mitomycin-C in refractory glaucoma. J. Ocul. Pharmacol., 1990, 6, 175-182.

Comper WD, Laurent TC: Physiological function of connective tissue polysaccharides. Physiol. Rev., 1978, 58, 255-315.

Franks WA, Hitchings RA: Complications of 5-fluorouracil after trabeculectomy. Eye, 1991, 5, 385389.

Goldberg RL, Toole BP: Hyaluronate inhibition of cell proliferation. Arthritis. Rheum., 1987, 30, 769-778.

Hellström $S$, Laurent $C$ : Hyaluronan and healing of tympanic membrane perforations. An experimental study. Acta Otolaryngol. (Stockh) Suppl., 1987, 442, 54-61.

Hakkansson L, Venge P: The molecular basis of the hyaluronic acid-mediated stimulation of granulocyte function. J. Immunol., 1987, 138, 43474352.

Jackson RL, Busch SJ, Cardin AD: Glycosaminoglycans: Molecular properties, protein interactions, and role in physiological processes. Physiol. Rev., 1991, 71, 481-539.

Khaw PT, Doyle JW, Sherwood MB, Smith MF, $M c$ Gorray $S$ : Effects of intraoperative 5-fluorouracil or mitomycin $\mathrm{C}$ on glaucoma filtration surgery in the rabbit. Ophthalmology, 1993, 100, 367-372. 
Kitazawa Y, Kawase K, Matsushita H, Minobe M: Trabeculectomy with mitomycin. A comparative study with fluorouracil. Arch. Ophthalmol., 1991, 109, 1693-1698.

Kivalo M, Raitta C: The effect of sodium-hyaluronate on scar tissue formation under a subconjunctival silicone implant in the rabbit. Acta Ophthalmol. (Copenh), 1991, 69, 672-679.

Kivalo M, Raitta C, Mononen T: A one-piece ocular drainage implant for glaucoma surgery: A preliminary report. Acta vet. Scand., 1992, 33, 317 324.

Laurent TC, Fraser JRE: The properties and turnover of hyaluronan. Ciba Foundation Symposium, 1986, 124, 9-29.

Laurent TC, Fraser JRE: Hyaluronan. FASEB J., 1992, 6, 2397-2404.

Lee DA, Flores RA, Anderson PJ, Leong KW, Teekhasaenee $C$, De Kater AW, Hertzmark E: Glaucoma filtration surgery in rabbits using bioerodible polymers and 5-fluorouracil. Ophthalmology, 1987, 94, 1523-1530.

Longaker MT, Chiu ES, Adzick NS, Stern M, Harrison MR, Stern R: Studies in fetal wound healing. Ann. Surg., 1991, 213, 292-296.

Mast BA, Haynes JH, Krummel TM, Diegelman RF, Cohen $I K$ : In vivo degradation of fetal wound hyaluronic acid results in increased fibroplasia, collagen deposition and neovascularization. Plast. Reconstr. Surg., 1992, 89, 503-509.

Molteno ACB, Straughan JL, Ancker E: Control of bleb fibrosis after glaucoma surgery by anti-inflammatory agents. S. Afr. Med. J., 1976, 50, 881-885.

Pape LG, Balazs EA: The use of sodium hyaluronate $\left(\right.$ Healon $\left.^{\mathrm{R}}\right)$ in human anterior segment surgery. Ophthalmology, 1980, 87, 699-705.

Pasquale LR, Thibault D, Dorman-Pease ME, Quigley HA, Jampel HD: Effect of topical mitomycin $\mathrm{C}$ on glaucoma filtration surgery in monkeys. Ophthalmology, 1992, 99, 14-18.

Raitta C, Setälä K: Trabeculectomy with the use sodium hyaluronate. A prospective study. Acta Ophthalmol. (Copenh), 1986, 64, 407-413.

Rydell N: Decreased granulation tissue reaction after installment of hyaluronic acid. Acta Orthop. Scand., 1970, 41, 307-311.
Shapiro MS, Thoft RA, Friend.J, Parrish RK, Gressel $M G$ : 5 -fluorouracil toxicity to the ocular surface epithelium. Invest. Ophthalmol. Vis. Sci., 1985, 26, 580-583.

Skuta GL, Parrish RK: Wound healing in glaucoma filtering surgery. Surv. Ophthalmol., 1987, 32, 149-170.

Skuta GL, Beeson CC, Higginbotham EJ, Lichter PR, Musch DC, Bergstrom TJ, Klein TB, Falck FY: Intraoperative mitomycin versus postoperative 5fluorouracil in high-risk glaucoma filtering surgery. Ophthalmology, 1992, 99, 438-444.

Watanabe J, Iwata K, Sawaguchi S, Nanba K: Trabeculectomy with 5-fluorouracil. Acta Ophthalmol. (Copenh), 1991, 69, 455-461.

Weigel PH, Fuller GM, LeBoeuf RD: A model for the role of hyaluronic acid and fibrin in the early events during the inflammatory response and wound healing. J. Theor. Biol., 1986, 119, 219234.

Wirt H, Bill A, Draeger J: Neue Aspekte in der operativen Behandling des Glaucoms. (A new aspect in the surgical treatment of glaucoma). Ophthalmology 1992, 89, 218-222.

\section{Sammandrag \\ Effekten av en intraoperativ injektion av hyaluronan under ett glaukomfiltrationsimplant $i$ kaninögat.}

Effekten av en enda intraoperativ injektion av hyaluronan på intraokulärttryck och inflammationsreaktion evaluerades hos 18 kaniner under 60 dagar.

I både hyaluronaninjicerade och kontrollögon stannade det intraokulärätrycket under hela uppföljningstiden på en nivå som var statistiskt signifikant lägre än det preoperativa värdet.

Från dag 7 till dag 60 var det intraokuläratrycket i de hyaluronaninjicerade ögonen lägre än i kontrollögon, men ingen statistiskt signifikant skillnad fanns mellan de båda grupperna.

Lagret av bindväv omkring implantet var mindre tätt under de första 17 dagarna av uppföljningsperioden $\mathrm{i}$ de hyaluronaninjicerade ögonen, också den inflammatoriska cellreaktionen förblev mera akut längre än i kontrollgruppen.

(Received November 15, 1996; accepted April 21, 1997).

Reprints may be obtained from: M. Kivalo, Section of Anatomy, Department of Basic Veterinary Sciences, P.O. Box 57, 00014 Helsinki University, Finland. E-mail: Matti.Kivalo@helsinki.fi, Fax: + 358970849799 , Tel: + 358970849542 